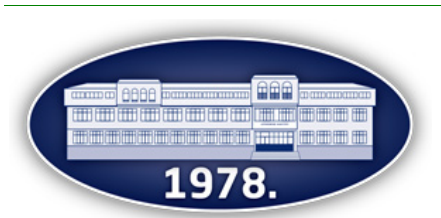

\title{
Digitalization in the meat chain
}

\author{
Ivan Nastasijević1 ${ }^{*}$, Slavica Vesković Moračanin ${ }^{1}$ \\ 1Institute of Meat Hygiene and Technology, Kaćanskog 13, Belgrade, Serbia \\ *Corresponding author: ivan.nastasijevic@inmes.rs
}

Received 28 September 2021; Accepted 8 December 2021

\begin{abstract}
A B S T R A C T
The meat supply chain should be regularly monitored to ensure the safety of products. Recent developments in Artificial Intelligence, Internet of Things and blockchain technologies will have a tremendous and disruptive effect on the meat supply chain system in terms of improving the monitoring and surveillance of hazards at multiple points along the meat chain (pre-harvest, harvest, post-harvest), in the farm-to-retail continuum, as well as providing better quality of information to consumers for informed decisions regarding food purchase. The farm-to-fork food chain continuum should be managed to provide an appropriate level of consumer protection (ALOP). This can be achieved by science-based risk assessment, which includes information about the prevalence and concentration of major public health hazards (epidemiological indicators) of zoonotic origin (Salmonella, Campylobacter, Listeria monocytogenes, Yersinia, Shiga toxin-producing Escherichia coli/STEC) in all modules along the food (meat) chain: farm - transport - slaughterhouse - meat processing - distribution - retail - consumers. The integration of digital technologies to the Food (Meat) Safety Management System or Meat Safety Assurance System will enhance the integration of Food Chain Information and Harmonized Epidemiological Indicators along the meat chain, from farm to retail (bottom-up) and vice versa from retail to farm (top-down). Meat chain digitalization will also increase the transparency and visibility of all actors involved in meat production, processing, distribution and retail (farmers, meat business operators, competent authorities, retailers), and provide the basis for benchmarking producers and retail chains, as well as pro-active consumer participation in defining future food policies at the national and global level.
\end{abstract}

Keywords: meat chain, meat safety, digitalization, internet of things, blockchain, artificial intelligence.

\begin{abstract}
И 3 В $О$ Д
Мониторинг ланца снабдевања месом треба да се регуларно спроводи у циљу осигурања безбедности производа. Недавни развој вештачке интелигенције, интернет ствари и блокчејн технологија имаће изванредан ефекат на систем производње и снабдевања месом у смислу унапређења мониторинга и надзора над опасностима у свим тачкама дуж ланца меса (примарна производња, клање/обрада и прерада/дистрибуција/малопродаја), у континууму фарма-малопродаја, као и обезбеђења бољег квалитета информација ка потрошачима за доношење информисаних одлука када је у питању куповина хране. Континуумом ланца хране „од фарме до виљушке” треба да буде управљано тако да се омогући одговарајући ниво заштите потрошача. То може да буде постигнуто научно базираном оценом ризика, што обухвата информације о преваленци и концентрацији главних опасности од значаја за јавно здравље (епидемиолошки индикатори) зоонотског порекла (Salmonella, Campylobacter, Listeria monocytogenes, Yersinia, шигатоксин-продукујућа Escherichia coli/STEC) у свим модулима дуж ланца хране (меса): фарма - транспорт - кланица - прерада меса - дистрибуција - малопродаја - потрошачи. Интеграција дигиталних технологија у систем управљања безбедности хране или систем за осигурање безбедности меса омогућиће бољу синтезу информација из ланца хране и хармонизованих епидемиолошких индикатора дуж ланца меса, од фарме до малопродаје (од дна ка врху) и обрнуто, од малопродаје до фарме (од врха ка дну). Дигитализација ланца меса ће такође повећати транспарентност и видљивост свих актера укључених у производњу, прераду, дистрибуцију и малопродају (фармера, субјеката у пословању храном, надлежних државних органа, малопродајних система) и поставити основу за међусобно упоређивање квалитета произвођача и малопродајних ланаца, као и проактивно учешће потрошача у дефинисању будуће политике у храни на националном и глобалном нивоу.
\end{abstract}

Кључне речи: ланац меса, безбедност меса, дигитализација, интернет ствари, блокчејн, вештачка интелигенција.

\section{Introduction}

Meat is considered the most valuable livestock product since it is composed of protein and essential amino acids, fat and fatty acids, minerals/microelements (zinc, iron), vitamins (B complex) (Bohrer, 2017; FAO, 2020) and other bioactive compounds with physiological activities (sequences of 2-30 amino acids that have a positive effect on consumer health and an important role in the prevention of metabolic syndrome diseases and mental illness). The main endogenous bioactive compounds in meat are as follows: conjugated linoleic acid (CLA) (anti-carcinogenic properties), coenzyme Q10 and carnosine (antioxidant and anti-aging effects), taurine (endocrine and immune system stimulation), creatine (improvement of muscle performance), choline (development of the central nervous system), and glutathione (potent detoxifying activity) (Carni Sostenibili, 2020; Vongsawasdi and Noomhorm, 2015). 
Meat nutritional value. Meat is food of high nutritional value and in most places in the world the consumption of meat is highly esteemed (McAfee et al., 2010). It is estimated that a relatively small percentage of the world population (2-10\%) choose not to consume meat, but rather to use vegetarian and/or vegan-based diet (Corrin and Papadopoulos, 2017). On the other hand, this percentage can still be considered significant on a global level. Therefore, it is important to obtain evidence-based data on the nutritional content and bioavailability of meat-based diets versus vegetarian/vegan-based diets to ensure better evaluation of food choices from the public health level (Sikorski, 1990). Since most non-meat foods contain only $20-60 \%$ of the protein density of meat, consideration needs to be made when replacing meat in the diet with non-meat foods. For example, the digestibility index of meat (all animal flesh) is the highest: 1 (100\%); followed by cooked beans 0.94 , milk 0.93 , cooked rice 0.92 , eggs 0.91 , wheat 0.85 , boiled soybean 0.80 , corn 0.66 , baked potato 0.52 (Ciuris et al., 2019).

Global meat production. World meat production is projected to double by 2050 , mostly in developing countries due to the development of their economy and the purchasing power of consumers who demand meat as a protein-rich product (OECD/FAO, 2016). The growing meat market provides a significant opportunity for livestock farmers and meat processors in these countries. It should be taken into consideration that increasing livestock production and the safe processing and marketing of hygienic meat and meat products still represent a big challenge (FAO, 2020). In the meat chain, poultry meat is the primary driver of growth in total meat production when it comes to expanding global demand for this animal protein, which is more affordable than red meats (OECD/FAO, 2016). The main reasons for making poultry the meat of choice are low production costs and low product prices, as well as its multi-confessional dimension (poultry meat is equally accepted and consumed throughout the world by adherents of all major religions - Christians, Muslims, Buddhists, etc.) (OECD/FAO, 2016). In the bovine meat sector, cow herd liquidation occurred in major producing regions, which led to a decrease in beef production in 2015 (OECD/FAO, 2016). Thereafter, beef production stabilized and increased from 2016 onwards, with higher carcass weight neutralizing the decline in cattle slaughter. Pig meat production increased from 2016, mainly driven by China, where herd size stabilized for a while after years of substantial reductions (i.e. a drop of 25 million pigs between 2012 and 2015). After a short period of consolidation of the pork sector, a decrease in pig meat production on a global scale was recorded from August 2018 due to the outbreak of African Swine Fever (ASF) in east Asia, which predominantly affected Chinese pig meat production, where several million pigs were culled in efforts to slow down and stop the spread of the disease (Mason-D`Croz et al., 2020). The sheep meat sector recorded an annual growth rate of $2.1 \%$ in the previous decade due to increased production in China, Pakistan, Sudan and Australia (OECD/FAO, 2016).

Global meat safety issues. Meat safety is always at the forefront of public health and socio-economic concerns (Sofos, 2008). Major meat safety challenges are associated with hazards that can be considered traditional, new or emerging, associated with increased virulence and/or low infectious dose and with resistance to antibiotics or other food related stresses (Sofos, 2008). These hazards enter the meat chain at multiple points along the farm - abattoir - meat processing - distribution - retail - consumer continuum (Nastasijević et al., 2020a). Traditional microbiological/parasitic hazards are Brucella spp., Mycobacterium bovis, Bacillus anthracis, Trichinella spp. and Taenia solium/bovis (cysticercosis). Emerging hazards are bacterial pathogens such as Shiga toxinproducing Escherichia coli (STEC) 0157:H7 and non0157, e.g. the "big six": 026, 045, 0103, 0111, 0121, 0145 (USDA FSIS, 2011) or 026, 0103, 0145, 0111, 0145 (EFSA, 2020), Salmonella, e.g. the "big five": S. Typhimurium, S. Enteritidis, S. Infantis, S. Virchow, S. Hadar (EFSA/ECDC, 2019), Campylobacter jejuni, Yersinia enterocolitica and Toxoplasma gondii, which are major pathogens affecting the safety of raw meat and poultry, while Listeria monocytogenes remains a concern in ready-to-eat (RTE) processed meat products (Nastasijević et al., 2017). Chemical hazards are related to environmental contaminants which may enter the meat chain (mycotoxins, heavy metals, PCBs/Dioxins), veterinary drugs (antibiotics, sulphonamides), hormones and food additives (nitrites, polyphosphates). Other challenges include the need for the development of rapid testing and pathogen detection methodologies with sufficient sensitivity and specificity, traceability systems (blockchain technology), and sensing systems (biosensors). Above all, focus is placed on the agreement and allocation of responsibilities between veterinary and public health authorities regarding monitoring and surveillance systems for zoonotic diseases (including foodborne ones), the establishment of a government policy regarding the maximum allowed contamination level appropriate level of protection (MACL-ALOP) for food which reaches the consumer (Nastasijević et al., 2020a), as well as the establishment of risk-based food safety objectives in meat production/processing, together with the complete and routine implementation of the risk-based food safety management system, hazard analysis and critical control points (HACCP).

Digitalization in the meat chain. The meat supply chain should be regularly monitored to ensure the safety of products. Healthy animals are an essential precondition for a safe food supply, since zoonotic diseases, including meat borne pathogens, present in meat and, in particular, ready-to-eat meat products are a threat to consumers. Information about livestock health, animal welfare and the prevalence of major meat borne hazards such as Salmonella, Campylobacter, STEC, L. monocytogenes, and Yersinia are of utmost importance for effective biosecurity control on farms. For example, early detection of these hazards in fecal samples, and monitoring blood levels of metabolites relevant for animal welfare (hormones) and animal health (acute phase proteins) can provide high-level control in the animal farming industry. For the purposes of meat safety monitoring and control in the meat supply chain continuum, there is a need for the dynamic introduction of digital technologies (Internet of Things (IoT) and development and optimization of point-of-care (PoC) sensing systems (e.g. biosensors) to monitor farm biosecurity and secure Food Chain 
Information (FCI) flow in the farm-to-slaughterhouse (F2SC) continuum (bottom-up and top-down).

Namely, in light of the fourth industrial revolution (4S) introducing a new era that builds and extends the impact of digitalization in new and unanticipated ways, there is still an unexplored world of opportunities to foster more effective animal health and welfare control and increase consumer protection via the interface of digital technologies and sensing systems. Therefore, the objectives of this review are as follows: a) to reflect on major challenges in the meat chain in the $21^{\text {st }}$ century related to the fourth industrial revolution, and b) emphasize the need for digitalization along the meat chain to ensure full traceability and early warning systems for the improvement of meat safety, as well as consumer protection and confidence in the food supply chain

\section{Materials and methods}

A literature review was performed by analyzing published scientific papers and major sources of information available in scholarly databases such as Web of Science, CAB Direct, national and intergovernmental guidelines. The official web-sites of selected national/international meat chain monitoring and surveillance schemes were also analyzed (e.g. OIE Digital Technologies and Implications for Veterinary Services, FDA New Era of Smarter Food Safety and FAO Digitalization and Innovation to Achieve SDGs). Therefore, this review identified articles (research and review papers, technical reports by international organizations) and databases published in the field of meat safety, zoonotic meat borne pathogens, digital technologies and sensing systems (Precision Livestock Farming) and their application in the meat supply chain, including public health impact. The search string was defined by the following key words: "meat safety", "meat chain", "digitalization", "sensing systems", "biosensors", "animal welfare", "animal health", "meat borne diseases", "fourth industrial revolution". The selection criteria chosen to identify articles that satisfy the scope and objectives of this review were as follow: 1) focus on meat safety monitoring and surveillance using well-established databases; 2) focus on the potential for the improvement of animal health, animal welfare and meat safety monitoring via digital technologies and sensing systems, and 3) future research. However, some geographical restrictions were applied, by including selected countries with experience in meat supply chain monitoring and surveillance programs using digital technology and sensing systems.

\section{Results and discussions}

Digitalization of the food (meat) value chain refers to the application of novel technologies, such as sensing systems and Internet of Things (IoT), to enhance the monitoring and surveillance of animal health, animal welfare and food safety aspects throughout the meat chain, e.g. pre-harvest (on-farm), harvest (abattoir), and post-harvest (processing, distribution, retail).

The development of mechanization in the early $19^{\text {th }}$ century, the automation initiated during the $1970 \mathrm{~s}$ (automated feeding systems, milking robots, manure management), the development of genetics and breeding, and data \& information associated with the development of internet from the 1990s and onwards had a significant impact on all aspects of daily activities and manufacture, including food systems (Raheem et al., 2019).

The world's population will reach around 9.1 billion people by 2050 (Figure 1), while food production will increase by $70 \%$ to cover additional food demand (UNDESA, 2017). It means that the world population will increase from the current 7.6 billion by around 1.5 billion in the following 30 years. The population in developing countries will reach around 8 billion by that time $(49 \%, 41 \%$ and $7 \%$ in Africa, Asia and South America, respectively), while the population in the developed world will remain relatively constant, around 1.2 billion, mainly due to steady population growth in the USA (4\%) (MSU, 2018).

Population growth 1950 - 2050

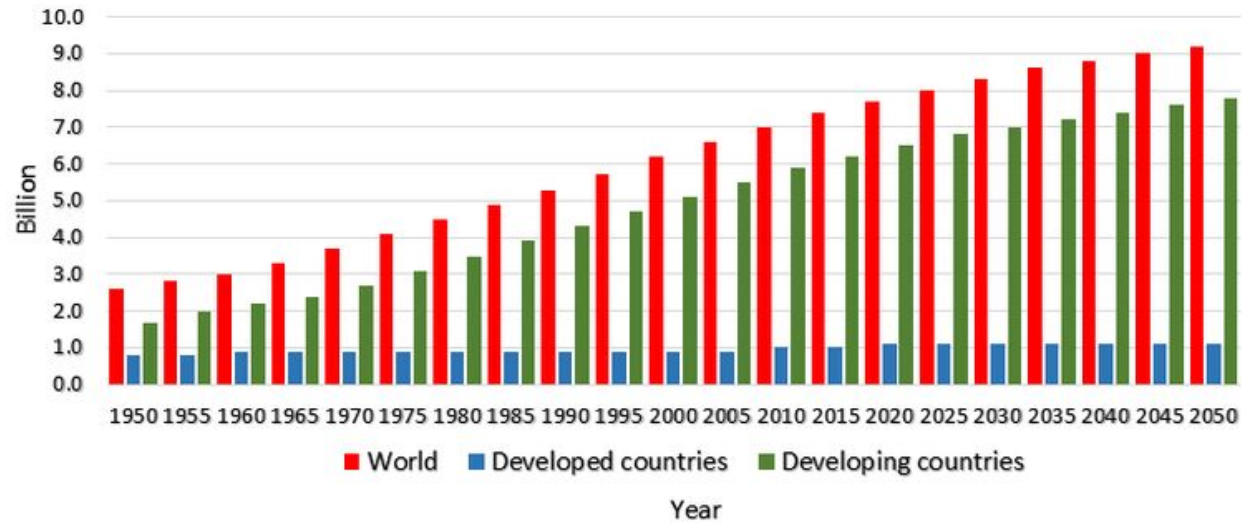

Figure 1. Estimated global population growth between 1950 and 2050 (adapted from MSU, 2018)

On the other hand, global meat production is projected to be $16 \%$ higher in 2025 than in the period up to 2015 (OECD/FAO, 2016) and, by 2050, global meat production will increase to 455 million tons (FAO, 2009). The major reason for this total increase in meat production is attributed to developing countries due to the development of their economy and the purchasing power of consumers who demand meat as a proteinrich product. Poultry meat is the primary driver of growth in total meat production in response to the 
expanding global demand for this animal product, which is more affordable than red meats (OECD/FAO, 2016).

To address the above mentioned challenges associated with increasing food demand due to rapid global population growth and to achieve the United Nations Sustainable Development Goals (SDGs), technological innovations, such as digitalization, will have to play an essential role in transforming agri-food systems, including the meat chain.

Advanced digitalization technology can help modern farms optimize economic contribution per animal/flock, reduce the use of antimicrobials, and improve overall animal health and welfare, thus providing the foundation for safe, good quality meat (Neethirajan et al., 2018; Neethirajan and Kemp, 2021).

\subsection{Digital technologies in meat chain monitoring and surveillance}

The introduction of digitalization into monitoring and surveillance throughout the meat chain, from farmto-retail, will certainly have a profound and disruptive impact on how farming and animal health systems are managed, including the operation of veterinary services (El Idrisi et al., 2021). These technologies rely on data based on advanced IoT and sensing systems technologies, such as (i) wireless, mobile, point-of-care technologies (biosensors) for animal health and welfare monitoring, disease surveillance, animal reproduction and behavior, reporting and information sharing, (ii) advanced data processing technologies (big data, algorithms) for early warning and uncovering of hidden patterns, predictions and correlation with animal health and welfare, and (iii) blockchain application for effective management of different inputs originating from biosensors.

The implementation of digital technologies will improve livestock health and productivity, reduce animal diseases, ensure the high quality and safety of meat, thus reducing public health risks via the environment-animal-human interface (One Health approach). In addition, the adoption and utilization of novel technologies will also make an influential contribution through solutions in tackling global challenges such as food security, global health, antimicrobial resistance, climate change, reduced natural resources and biodiversity loss.

Precision livestock farming (PLF) technologies apply the principles of control engineering to automate and provide early warning in livestock farming, allowing farmers to monitor large populations of animals for health and welfare, detect issues with individual animals in a timely manner, and even anticipate issues before they occur based on previous data (Benjamin and Yik, 2019). Recent examples of PLF technologies include monitoring cattle and sheep behavior (jaw movement, grazing and feeding behavior, animal movement) (Laca and DeVries, 2000; Herinaina et al., 2016), detecting vocalizations (screams in pigs), monitoring coughs in multiple species to identify respiratory illness, breath analyses (Burciaga-Robles et al., 2009; Knobloch et al., 2009), and identifying different metabolites (perspiration - sodium and lactate levels, tears - glucose level) (Leopold et al., 2014), saliva - uric acid (Yamaguchi et al., 2013), body temperature (inflammation or pregnancy) and progesterone - pregnancy (Neethirajan et al., 2017).
PLF can enable farmers monitor infectious diseases in farm animals, providing electronic information transfer, e.g. from biosensors, in optimizing animal health, production and management processes on farm, thus improving food safety and availability, as well as maximizing efficient resource use (Norton et al., 2019).

The application of PLF implies measuring variables on the animals (health, welfare, behavioral changes, good productive performance, good reproductive performance) (Tullo et al., 2019), modeling these data to select information (algorithm), and then using these models in real time for monitoring and control purposes. The philosophy of PLF is to assist farmers in monitoring the health and welfare status of their animals in a fully automated and continuous manner (Nastasijević et al., 2017). By doing so, the farmers are able to make quick, pro-active and evidence-based decisions to adjust to changes in animal requirements. The nanobiosensors utilized to detect changes in animal physiology are integrated with the Internet-ofThings (IoT) technology (cloud servers, smart phone applications) for the rapid and real-time reporting of livestock condition on a farm. Therefore, PLF supports the intelligent management of animal health including rapid alert systems to meet the growing global demand for animal proteins, while guaranteeing animal health and welfare, the future sustainability of animal farming, as well as improved food safety (Berckmans, 2017).

\subsection{Digitalization on farm}

Digital farming (e.g. smart farming \& agriculture 4.0) has potential to transform food animal farming systems to become more sustainable by reducing the use of antimicrobials (thus preventing the emergence of antimicrobial resistance, AMR), promoting animal health and welfare, and creating conditions for achieving sufficient supplies of good quality and safe food. Having in mind that global agri-food systems are already facing challenges regarding the increasing demand for animal protein, the process of digitalization of livestock farming can have a beneficial impact by optimizing and increasing overall productivity in a sustainable manner without further pollution of soil, water and other agro-ecological systems, as well as improving resilience and adaptation of the food system to climate change (Cole et al., 2018; Shang et al., 2021).

Digital farming technologies include a broad spectrum of devices and applications, such as sensing systems (e.g. biosensors for the wireless transfer of information based on biochemical interaction between the biomarker and the bioreceptor - Figure 2), Artificial Intelligence/AI (developed algorithms for data processing), cloud computing, IoT, blockchain, as well as smart phone applications for real-time access to obtained information and decision support (Torky and Hassanein, 2020; Nastasijevic et al., 2020b).

It is of utmost importance to recognize and understand the mechanisms of adoption and dissemination of digital farming technologies by farmers and system level (collection and organization of entities relevant for the adoption and dissemination). The adoption behavior is multidimensional and depends not only on farmers but also on the technical, structural, political and economic conditions of the agri-food chain; the adoption of digital farming can also evolve over time, based on the 
behavior of farmers and their interactions with the legislative, commercial and political environment (Alexander et al., 2013; Shang et al., 2021). The most important factors influencing the adoption of digital farming technologies are defined in 6 groups (Shang et al., 2021): (I) farm characteristics (farm size, biophysical conditions, livestock ownership, land use, labor availability, farm succession); (II) operator characteristics (education, age, farming as a main occupation, income, computer use, farming experience, innovativeness, knowledge \& capacity, risk preference); (III) interactions (consultants, extensions, farmers' associations, technology providers, trade shows, workshops, information sources); (IV) institutions (subsidy/credit, legislation); (V) attributes of technology (relative advantage - perceived usefulness, complexity - ease of use, compatibility, data safety, trialability, observability); (VI) psychological factors (attitude, subjective norm, perceived behavioral control). The most significant factors influencing the adoption of digital farming include: farm size and biophysical condition, level of education and age of farmers, quality of interaction with consultants and extension services, availability of subsidies and credits, usefulness and ease of use of the technology, and farmers' attitude (Shang et al., 2021).

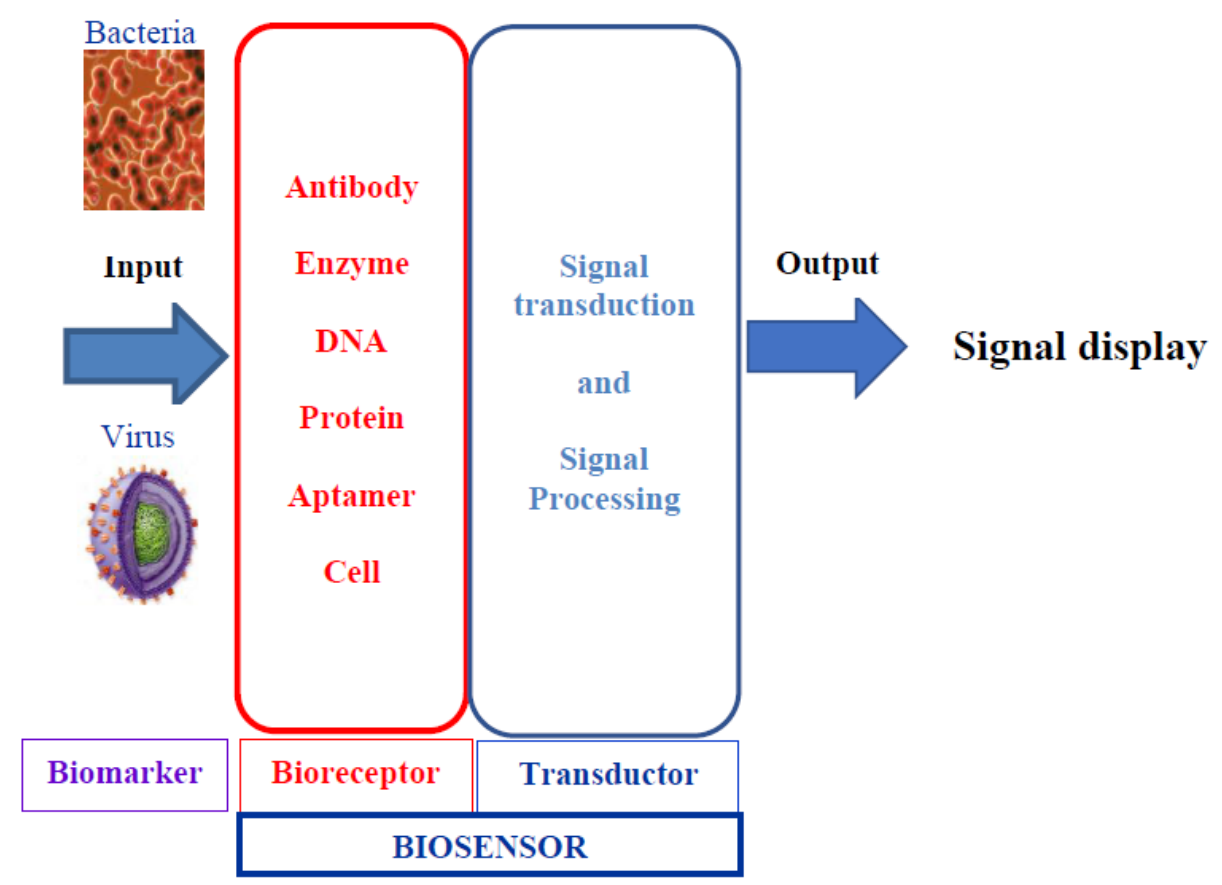

Figure 2. Biosensor principle based on the biochemical reaction between the biomarker and the bioreceptor (adapted from Vidic et al., 2017)

The examples of digital farming are associated with the interface biosensors - cloud computing - IoT smart phone applications providing valuable and realtime information on animal health and welfare, including some reproductive and nutritional issues. For example, the following animal health and physiological conditions, including animal welfare status, can be effectively monitored by sensing systems: lameness in solipeds (acceleration data by ear tags); locomotion in cows (automatic 3D vision); grazing behavior in cattle and sheep (acoustic sensor for identifying jaw movement, chewing and biting) (Laca and DeVries, 2000); physiological and behavioral stress in animals; vocalization sounds of broilers in response to environmental conditions; cattle and pig cough as an indicator of respiratory disease (Neethirajan et al., 2017); drinking behavior of animals; health status via body temperature (video-based infrared thermography camera); hormone profile for estrus detection (Neethirajan et al., 2017); detection of animal diseases (e.g. brucellosis, bovine tuberculosis, bovine respiratory disease/BRD, bovine viral diarrhoea/BVD, avian influenza virus/AIV, foot and mouth diseases/FMD, mastitis) (Fend et al., 2005; Wang et al., 2009; Knobloch et al., 2009; Montrose et al., 2015; Yang et al., 2015; Tarasov et al., 2016; Martins et al., 2019); and fecal shedding of food borne pathogens (e.g.
Salmonella, Campylobacter, Cl. perfringens), which is important from the perspective of meat safety (Nastasijević et al., 2019). Further, sensing systems can also represent an added value in providing supplemental information for other methods related to animal welfare assessment based on nutritional status and Body Condition Scoring (BCS) (Lalovic et al., 2020).

Namely, the concentration of major zoonotic food (meat) borne pathogens can be accurately detected by innovative sensing systems (biosensors) based on specific biomarkers for pathogens affecting animal health, such as DNA receptors, glycan, aptamers and antibodies (Halachmi, 2015). A biosensor recognizes a target biomarker characteristic of a pathogen via an immobilized sensing element - a bioreceptor (monoclonal antibody, RNA, DNA, glycan, lectin, enzyme, tissue, whole cell). The specific biochemical interaction between the biomarker and the bioreceptor is then converted into a measurable signal by the transductor (Figure 2). Paper-based platforms (microarrays) can be effectively used as affordable, rapid and user-friendly sensing systems under real farm conditions (Vidić et al., 2017). 


\subsection{Digitalization in abattoirs}

To date, there has been limited evidence on the wide commercial and routine adoption of digitalization in abattoirs. However, there are some promising steps towards the transition to digital technologies. Currently, the most frequently used approach is the computer vision system (CVS) monitoring of pathological lesions on carcasses and internal organs, as well as fecal contamination on carcasses (Blagojević et al., 2021). Namely, computer vision, digital image processing and digital image analysis are terms used to describe the process of digital image acquisition (Fernandes et al., 2020). Since regular and routine performance of official veterinary meat inspection protocols at remote small- and medium-scale abattoirs and game handling establishments are usually associated with a relatively high cost of official control per inspected animal, there is potential for cost reduction via live-streamed video generated by CVS (Almqvist et al., 2021).

The potential and benefit of using CVS in abattoirs have been increased in the European Union (EU) since 2014, when a legislative shift was made to allow for a purely visual post-mortem inspection of carcasses of pigs reared under 'controlled conditions', essentially meaning indoors, in order to omit the palpation- and incision-based inspection that was previously necessary (Hill et al., 2013; EC, 2014). In other cases, when "the epidemiological or other data from the holding of provenance of the animals, the food chain information or the findings of ante-mortem inspection and/or post-mortem visual detection of relevant abnormalities indicate possible risks to public health, animal health or animal welfare, the carcasses and offal of pigs are to undergo additional post-mortem procedures using incision and palpation" (Commission Regulation (EC) 218/2014).

The application of biosensors (linked with cloud computing and IoT) in abattoirs for the purposes of meat safety monitoring has been very much limited. On the other hand, progress in developing sensing systems has been recorded in recent years, resulting in the creation of biosensors for the detection of food (meat) borne pathogens, such as lateral flow, aptamer-based biosensors for the in-situ quantitative detection of $S$. Enteritidis and E. coli 0157:H7 at a sensitivity level of 10 colony forming units (CFU)/mL, respectively (Fang et al., 2014; Wu et al., 2015) or DNA-based sensors for the detection of Campylobacter in meat (poultry) samples at a detection level of $1.5 \times 10^{1} \mathrm{CFU} / \mathrm{g}$ (Manzano et al., 2015) or cell-based sensors which have mammalian cells as sensing elements to detect pathogens or toxins of Clostridium perfringens (Yoo et al., 2016). The regular and routine use of such biosensors is still not feasible as their performance and detection limits were mainly tested with enriched bacterial suspensions (in vitro) with the scarcity of data when using a matrix from a real production environment (e.g. straw, feces, blood).

\subsection{Digitalization in meat distribution and retail}

The introduction and adoption of digital technologies throughout the meat distribution and retail sector have already been recognized. The initial use of digitalization is related to the continuous time/temperature $(\mathrm{t} / \mathrm{T})$ monitoring of fresh meat (chilled or frozen) via data loggers and/or RadioFrequency Identification (RFID) tags (Jakubowski, 2015) connected via wireless mode with appropriate software (IoT/blockchain approach) and/or smart phone applications; recently, this has evolved to the level of machine learning methods used to predict temperature and even to detect breaks in the cold chain (Loisel et al., 2021); and/or "smart-packaging" (sensors measuring $\mathrm{T}$ or Volatile Organic Compounds/VOCs associated with meat spoilage) during distribution, storage and presentation in retail display cabinets (Mohebi and Marquez, 2015).

The UN World Health Organization has advocated cooperation between competent authorities, manufacturers and consumers to help ensure food safety in global food trade taking into consideration the cross-border nature and complexity of modern food supply chains (WHO, 2020). In addition, the global COVID-19 pandemic has increased consumer awareness of food supply chain transparency. Public concern has arisen regarding food safety and more consumers are expected to carefully select the brands they purchase. Digital traceability solutions such as "smart labeling" and "digital tracing", which provide contact-free and secure product information in a realtime environment, can play a role in reassuring consumers that products are safe to eat (Euromonitor, 2020).

In light of such recommendation, the dynamic process of digitalization of the food (meat) supply chain is of utmost importance in providing good quality, safety and traceability information to consumers, based on which they can make informed choices when purchasing meat/meat products.

Digitalization in the meat supply chain should be based on the integrated farm-to-retail approach to cover all modules along the meat chain, e.g. pre-harvest (farm), harvest (abattoir), and post-harvest (meat processing, distribution, retail), and enable full traceability at the point of retail.

Consumers should also take their part of responsibility related to meat handling and preparation, which belongs to the level of food safety culture. Interestingly, blockchain technology has been overshadowed by investments in Artificial Intelligence (AI) and IoT. Namely, huge price drops in digital sensors such as RFID tags and artificial intelligence software have made food businesses more interested in investing in AI and IoT over blockchain.

Although COVID-19 has put a spotlight on the application of blockchain in food safety and sustainability-based traceability, high costs and lack of clear use cases remain major obstacles to its adoption (Euromonitor, 2020). For example, the use of blockchain technology in the farm-to-retail continuum must be smooth to avoid disruption of existing farming practices and to enable easy adoption. In addition, farmers should not be faced with large financial burdens and governments should potentially offer subsidies or affordable credits. On the other hand, digital technology will provide greater transparency across the food chain to farmers, giving them access to valuable information (Figure 3). 


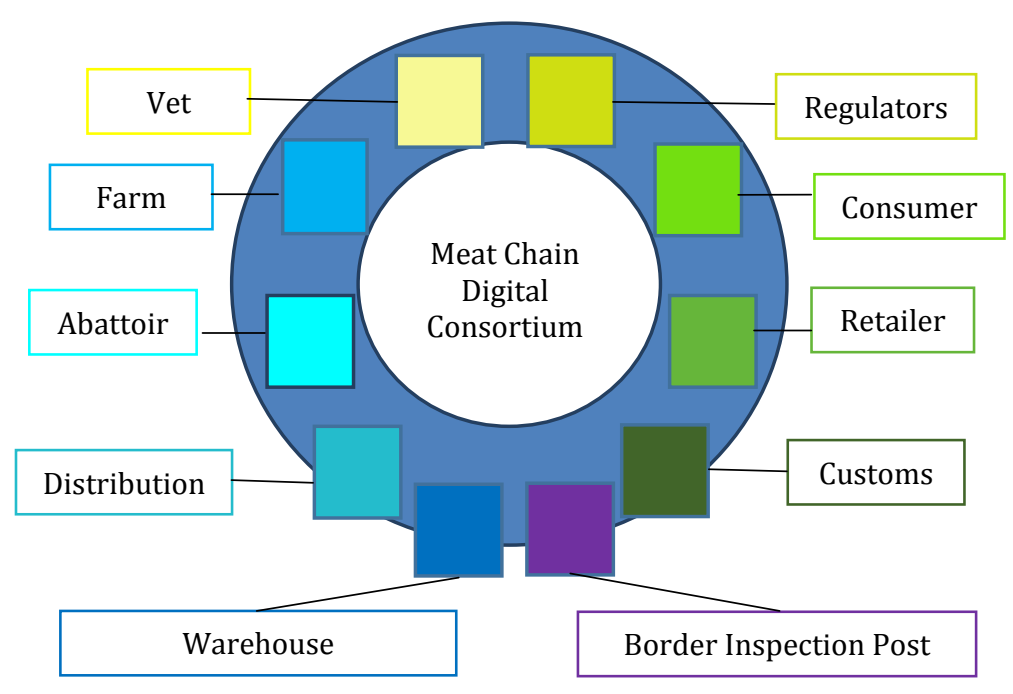

Figure 3. Example of the digitalization model in the meat supply chain (blockchain, AI/IoT)

\subsection{New business model and retail modernization}

In the era of the fourth industrial revolution, where the use of digital technologies is becoming conditio sine qua non in day-to-day life, including the food production and supply chain, the technology that automatically monitors product risk factors (animal health and welfare farm conditions, time, temperature, tamper-resistant packaging, potential for crosscontamination, traceability) will be encouraged. The key stakeholders involved in the food (meat) chain should be motivated to adopt the new business model, e.g. farmers, meat business operators (abattoirs, meat processing), manufacturers of food ingredients, food delivery companies, restaurants, retailers.

Retailers should be encouraged to conduct an independent review of traditional retail food safety programs (aiming for the prevention of food borne diseases and communication with suppliers and consumers), as well as to advance controls of their food safety management in terms of hygienic and technical conditions (facility and equipment design) and use of 'smart kitchen' equipment (for automated time and temperature monitoring).

Special emphasis should be placed on consumers and their participation in the food chain related to evidence-based food choices and educational materials (training manuals and leaflets) on the handling of food purchased or delivered to their home (in particular when it comes to e-commerce and home food delivery) to create a food safety culture at home.

The successful development and adoption of the new business model for the transformation of the food chain are based on the effective and efficient use of digital technologies and their interface with stakeholders throughout the food chain, in particular consumers (e.g. smart-phone applications providing real-time information on a food product from the label barcode).

\subsection{Digitalization in the Farm-to-Retail Food Safety Management System (FSMS)}

In light of forecasted rapid population growth, the global demand for meat and meat products is about to be increased by $40 \%$ in the following 15 years. A major challenge within the next 10 years is how to enable continuous monitoring of animal health within big groups of animals (Berckmans, 2017). Due to the increasing number of animals and the decreasing number of farmers, every farm will house more animals. In the future, a single farm (or animal city) may host 25,000 milking cows, 200,000 fattening pigs, or a few million broilers. Infections in such big groups can have disastrous economic and public health consequences (Berckmans, 2017). For example, in the EU during 2019, 27 Member States reported 5,175 food-borne outbreaks involving 49,463 cases of illness, 3,859 hospitalizations and 60 deaths. In addition, 117 outbreaks, 3,760 cases of illness and 158 hospitalizations were communicated by six non-MS. It has to be highlighted that L. monocytogenes-associated outbreaks in the EU were remarkable since this agent was responsible for 349 cases of illness and more than $50 \%$ of total outbreak associated deaths (31 deaths; 10 deaths more than in 2018; 29 more than in 2017). Most of the deaths were due to the consumption of meat and meat products (EFSA/ECDC, 2019). Parallel to this, the overuse and misuse of antibiotics in farm animals can lead to increased occurrence of antimicrobial resistance (AMR) associated with food (meat) consumption; AMR outbreaks significantly increased from $10.4 \%$ in 2014 to $14.9 \%$ in 2017 (ECDC, 2018). The continuous and efficient monitoring of the use of antibiotics in food animals and public and/or regulatory pressure for antibiotic reduction can decrease AMR development and consequently reduce consumer exposure. Digital technologies can play an important role in securing effective and real-time monitoring of animal health, welfare, infection diseases and AMR. The information collected in the continuous digital monitoring system should be incorporated into Food Chain Information (FCI) in both directions, farm- 
to-retail (bottom-up) and retail-to-farm (top-down). Such information (sensing systems, blockchain, AI, IoT) should provide a platform for decision-making by risk managers (veterinary inspection, and/or authorized personnel by FBO) in the meat safety assurance system (MSAS) and should also be based on Harmonized Epidemiological Indicators (HEIs) to enable the effective implementation of the FSMS (Figure 4).

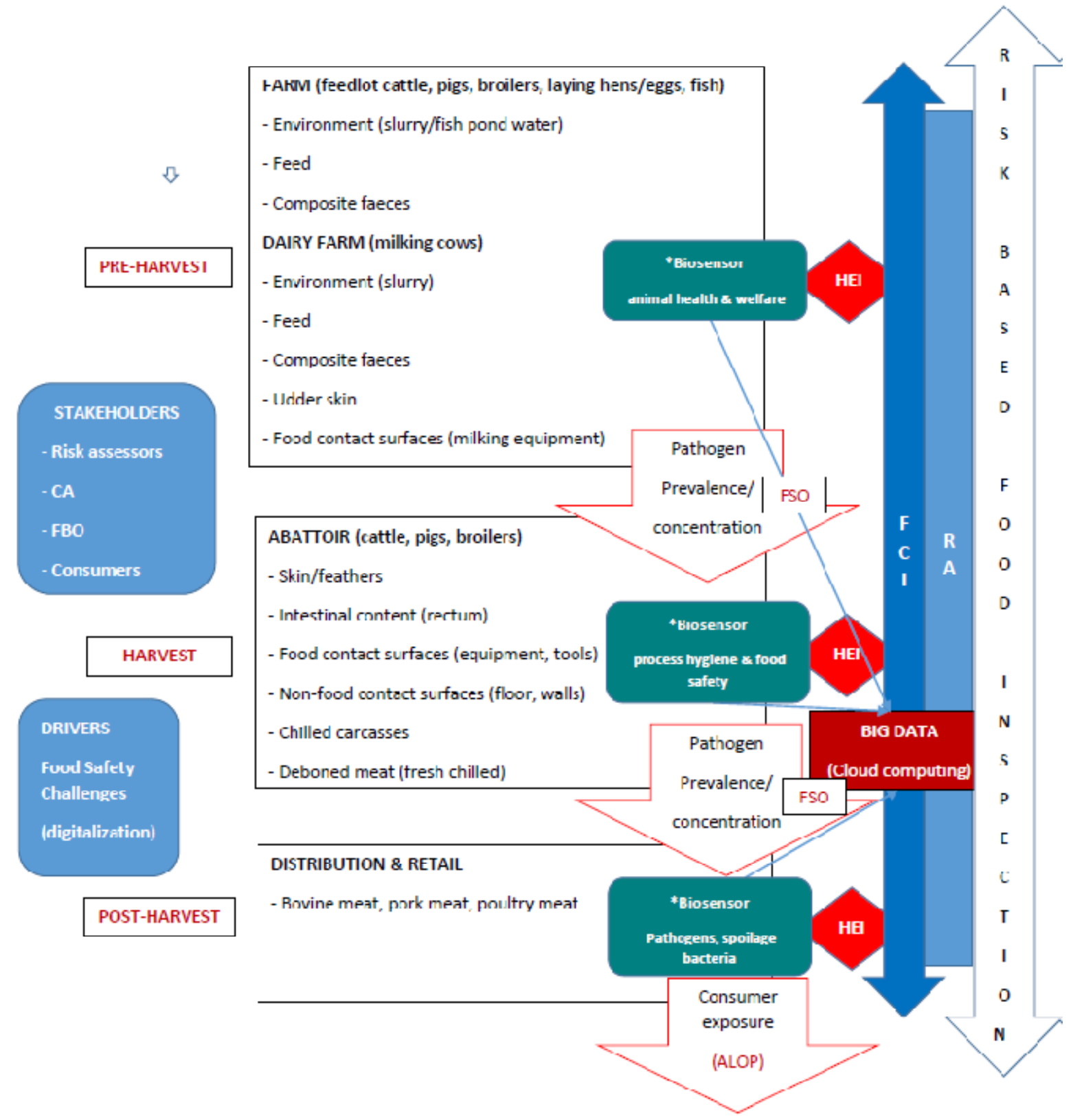

*Indicators detected by biosensor: Pathogen (e.g. Salmonella, Campylobacter), Animal health (Acute Phase Proteins), Animal welfare (hormones)

ALOP - Appropriate Level of Consumer Protection

CA - Competent Authorities

FBO - Food Business Operators

FCI - Food Chain Information

FSO - Food Safety Objective

HEI - Harmonized Epidemiological Indicators

RA - Risk Analysis (risk assessment, risk management, risk communication)

Figure 4. Food Safety Management System (FSMS) model for the digitalized meat chain

It is worth noting that an epidemiological indicator is defined as "the prevalence or the concentration of the hazard at a certain stage of the food chain or an indirect measure of the hazard that correlates with the human health risk caused by the hazard" (EFSA, 2013). Digitalization along the meat chain can enable the integration of FCI and HEIs for the improvement and modernization of meat inspection methods and the food safety risk analysis in the farm-to-retail continuum. It is foreseen that HEIs will be used in the bovine/pig/poultry carcass meat safety assurance system (farm-to-chilled carcass system) to help 
categorize farms/herds and abattoirs according to the risk related to the hazards, and set hazard-based targets in/on bovine/pig carcasses and, when appropriate, in bovine/pig farms and herds (Table 1).

Table 1.

Example of Harmonized Epidemiological Indicators for Salmonella in the pig carcass safety assurance system (EFSA, 2011)

\begin{tabular}{|c|c|c|c|}
\hline $\begin{array}{l}\text { Indicator } \\
\text { (animal/food category) }\end{array}$ & Meat chain phase & $\begin{array}{l}\text { Analytical/ } \\
\text { diagnostic method }\end{array}$ & Sample \\
\hline $\begin{array}{l}\text { HEI 1: Salmonella in breeding } \\
\text { pigs }\end{array}$ & Farm & $\begin{array}{l}\text { Microbiology } \\
\text { (detection and serotyping) }\end{array}$ & $\begin{array}{l}\text { Pooled (composite) } \\
\text { feces sample }\end{array}$ \\
\hline $\begin{array}{l}\text { HEI 2: Salmonella in fattening } \\
\text { pigs prior to slaughter }\end{array}$ & Farm & $\begin{array}{l}\text { Microbiology } \\
\text { (detection and serotyping) }\end{array}$ & $\begin{array}{l}\text { Pooled (composite) } \\
\text { feces sample }\end{array}$ \\
\hline $\begin{array}{l}\text { HEI 3: Controlled housing } \\
\text { conditions on farm }\end{array}$ & Farm & Auditing & $\mathrm{N} / \mathrm{A}$ \\
\hline $\begin{array}{l}\text { HEI 4: Transport and lairage } \\
\text { conditions }\end{array}$ & Transport and lairage & $\begin{array}{l}\text { Auditing of time, mixing of } \\
\text { batches and reuse of pens in } \\
\text { lairage }\end{array}$ & $\mathrm{N} / \mathrm{A}$ \\
\hline $\begin{array}{l}\text { HEI 5: Salmonella in fattening } \\
\text { pigs - evisceration stage }\end{array}$ & Abattoir & $\begin{array}{l}\text { Microbiology } \\
\text { (detection and serotyping) }\end{array}$ & Ileal content \\
\hline $\begin{array}{l}\text { HEI 6: Salmonella in fattening } \\
\text { pigs - carcasses after slaughter } \\
\text { before chilling }\end{array}$ & Abattoir & $\begin{array}{l}\text { Microbiology } \\
\text { (detection and serotyping) }\end{array}$ & Carcass swabs \\
\hline $\begin{array}{l}\text { HEI 7: Salmonella in fattening } \\
\text { pigs - carcasses after slaughter } \\
\text { and after chilling }\end{array}$ & Abattoir & $\begin{array}{l}\text { Microbiology } \\
\text { (detection and serotyping) }\end{array}$ & Carcass swabs \\
\hline
\end{tabular}

Risk managers should decide on the most appropriate indicator(s) to be used, either alone or in combinations, at national, regional, abattoir or farm/herd level, depending on the purpose and the epidemiological situation. It is recommended that risk managers should define harmonized requirements for the controlled housing conditions of farms. Evidently, there is a need for the additional improvement FCI/HEIs and their integration into the FSMS in the farm-to-retail continuum, including the development of HEIs up to the retail level, to ensure the inclusion of risk assessment data from the post-harvest meat chain module (distribution, retail and food safety culture). This should be effectively achieved by the dynamic digitalization of the meat supply system to provide benefits for all major stakeholders in the meat chain (farmers, meat business operators, competent authorities, consumers).

\section{Conclusions}

The digitalization in the meat chain is coming with the fourth industrial revolution (4S). Recent developments in Artificial Intelligence, Internet of Things and blockchain technologies will have a tremendous and disruptive effect on the meat chain supply system in terms of improving the monitoring and surveillance of hazards at multiple points along the meat chain (pre-harvest, harvest, post-harvest), in the farm-to-retail continuum, as well as providing better quality of information to consumers for informed decisions regarding food purchase. The farm-to-fork food chain continuum should be managed to provide an appropriate level of consumer protection (ALOP). This can be achieved by science-based risk assessment, which includes information about the prevalence and concentration of major public health hazards (epidemiological indicators) of zoonotic origin (Salmonella, Campylobacter, Listeria monocytogenes, Yersinia, Shiga toxin-producing Escherichai coli/STEC) in all modules along the food (meat) chain: farm transport - slaughterhouse - meat processing distribution - retail - consumers.

The integration of digital technologies to the Food (Meat) Safety Management System or Meat Safety Assurance System will enhance the integration of Food Chain Information and Harmonized Epidemiological Indicators along the meat chain, from farm to retail (bottom-up) and vice versa from retail to farm (topdown). Further, meat chain digitalization will increase the transparency and visibility of all actors involved in meat production, processing, distribution and retail (farmers, meat business operators, competent authorities, retailers), and provide the basis for benchmarking producers and retail chains, as well as pro-active consumer participation in defining future food policies at the national and global level. However, the current FSMS approach is based on the farm-tochilled carcass continuum and there are no defined harmonized epidemiological criteria at the retail level. Therefore, there is a need for future and deeper research, which should include the development of HEIs at the distribution/retail level and their integration into the digitalized meat safety assurance system.

\section{Acknowledgment}

This study was supported by the Innovation Fund of the Republic of Serbia, Proof of Concept program, under the Contract (No. 161, dated September 9, 2020) 
on the implementation of the project "Development and Integration of Microfluidic Biosensors for Meat Safety Monitoring in the Farm-to-Slaughterhouse Continuum" - DIBMES (ID5524), and by the Ministry of Education, Science and Technological Development of the Republic of Serbia, under the Contract on research funding in 2021 (No. 451-03-9/2021-14/200050, dated February 5, 2021).

\section{Declaration of competing interest}

Authors declare that no personal and/or financial relationship with other people or organizations is present in this review.

\section{References}

Alexander, P., Moran, D., Rounsevell, M.D.A., Smith, P. (2013). Modelling the perennial energy crop market: the role of spatial diffusion. Journal of The Royal Society Interface, 10, 20130656. https://doi.org/10.1098/rsif.2013.0656.

Almqvist, V., Berg, C., Hultgren, J. (2021). Reliability of remote post-mortem veterinary meat inspections in pigs using augmented-reality live-stream video software. Food Control, 125, 107940 https://doi.org/10.1016/j.foodcont.2021.107940.

Benjamin, M., Yik, S. (2019). Precision livestock farming in swine welfare: a review for swine practitioners. Animals, 9(4), 133, https://doi.org/10.3390/ ani9040133.

Berckmans, D. (2017). General introduction to precision livestock farming. Animal Frontiers, 7(1), 6-11.

Blagojević, B., Nesbakken, T., Alvseike, O., Vågsholm, I., Antic, D., Johler, S., Houf, K., Meemken, D., Nastasijević, I., Vieira Pinto, M., Antunovic, B., Georgiev, M., Alban, L. (2021). Drivers, opportunities, and challenges of the European risk-based meat safety assurance system. Food Control, 124 , https://doi.org/10.1016/j.foodcont.2021.107870.

Bohrer, B. M. (2017). Review: Nutrient density and nutritional value of meat products and non-meat foods high in protein. Trends in Food Science and Technology, 65, 103112.

Burciaga-Robles, L.O., Holland, B.P., Step, D.I., Krehbiel, C.R., McMillen, G.I., Richards, C.J., Sims, L.E., Jeffers, J.D., Namjou, K, McCann, P.J. (2009) Evaluation of breath biomarkers and serum haptoglobin concentration for diagnosis of bovine respiratory disease in heifers newly arrived at a feedlot. American Journal of Veterinary Research, 70(10), 1291-1298.

Carni Sostenibili. (2020). The bioactive compounds of the meat. https://www.carnisostenibili.it/en/the-bioactivecompounds-of-meat/ (accessed on August 23, 2021).

Ciuris, C., Lynch, H.M., Wharton, C. \& Johnston, C.S. (2019). A comparison of dietary protein digestibility, based on DIAAS scoring, in vegetarian and non-vegetarian athletes. Nutrients, 11 , https://doi.org/10.3390/nu11123016.

Cole, M.B., Augustin, M.A., Robertson, M.J., Manners, J.M. (2018). The science of food security. npj Science of Food, 2(14), https://doi.org/10.1038/s41538-018-0021-9.

Corrin, T., Papadopoulos, A. (2017). Understanding the attitudes and perceptions of vegetarian and plant-based diets to shape future health promotion programs. Appetite, 109, 40-47.

ECDC. (2018). Surveillance of antimicrobial resistance in Europe - Annual report of the European Antimicrobial Resistance Surveillance Network (EARS-Net) 2017. Stockholm: ECDC. ISBN 978-92-9498-279-7. DOI $10.2900 / 230516$.

EFSA. (2011). Technical specifications on harmonised epidemiological indicators for public health hazards to be covered by meat inspection of swine. EFSA Journal, 9(10), 2371.
EFSA. (2013). Scientific Opinion on the public health hazards to be covered by inspection of meat (solipeds). EFSA Journal 11(6), 3263.

Euromonitor (2020). Digital Traceability: A Future of Transparency in Food Sourcing. https://www.euromonitor.com/digital-traceability-afuture-of-transparency-in-food-sourcing/report (accessed on September 24, 2021).

EFSA/ECDC. (2019). The European Union One Health 2018 Zoonoses Report. EFSA Journal, 17(12), 5926.

EFSA. (2020). Pathogenicity assessment of Shiga toxinproducing Escherichia coli (STEC) and the public health risk posed by contamination of food with STEC. EFSA Journal,18(1), 5967

EC, European Commission. (2014). Commission regulation (EC) No 218/2014 of 7 March 2014 amending Annexes to Regulations (EC) No 853/2004 and (EC) No 854/2004 of the European Parliament and of the Council and Commission Regulation (EC) No 2074/2005. Official Journal of the European Union, 69, 95-98. http://eurlex.europa. eu/

Fang, Z, Wu, W, Lu, X, Zeng, L. (2014). Lateral flow biosensor for DNA extraction-free detection of Salmonella based on aptamer mediated strand displacement amplification. Biosens Bioelectron, 56, 192-197.

FAO. (2009). How to Feed the World in 2050. http://www.fao.org/fileadmin/templates/wsfs/docs/ex pert_paper/How_to_Feed_the_World_in_2050.pdf (accessed on September 23, 2021).

FAO. (2020). Meat and Meat Products. http://www.fao.org/ag/againfo/themes/en/meat/home. html (accessed on August 23, 2021).

Fend, R., Geddes, R., Lesellier, S., Vordermeier, H-M., Corner, L.A.L., Gormley, E., Costello, E., Hewinson, R.G., Marlin, D.J., Woodman, A.C., Chambers, M.A. (2005). Use of an electric nose to diagnose Mycobacterium bovis infection in badgers and cattle. Journal of Clinical Microbiology, 43(4), 1745-1751.

Fernandes, A.F.A., Dórea, J.R.R., de Magalhães Rosa. G.J. (2020). Image analysis and Computer Vision Applications in Animal Sciences: An overview. Frontiers in Veterinary Science, 7 , 551269. https://doi.org/10.3389/fvets.2020.551269.

Halachmi, I. (2015). Precision livestock farming applications. Wageningen Academic Publishers. 328. ISBN: 978 908686-268-9.

ttps://doi.org/10.3920/978-90-8686-815-5.

Herinaina, A.I., Bindelle, J., Mercatoris, B., Lebeau, F. (2016). A review on the use of sensors to monitor cattle jaw movements and behaviour when grazing. Biotechnology, Agronomy and Society and Environment, 23(S1), 273-286.

Hill, A., Brouwer, A., Donaldson, N., Lambton, S., Buncic, S., Griffiths, I. (2013). A risk and benefit assessment for visual-only meat inspection of indoor and outdoor pigs in the United Kingdom. Food Control, 30, 255-264.

Jakubowski, T. (2015). Temperature Monitoring in the Transportation of Meat Products. Journal of Food $\begin{array}{lll}\text { Processing and Technology, 6, } 10 . & .\end{array}$ http://dx.doi.org/10.4172/2157-7110.1000502.

Knobloch, H., Kohler, H., Commander, N., Reinhold, P., Turner, C., Chambers, M., Pardo, M., Sberveglieri, G. (2009). Volatile organic compounds (VOC) analysis for disease detection: proof of principle for field studies detecting paratuberculosis and brucellosis. AIP Conference Proceedings, 195-197.

Laca, E.A., DeVries, M.F.W. (2000). Acoustic measurement of intake and grazing behaviour of cattle. Grass and Forage Science, 55(2), 97-104.

Lalović, M., Krajisnik, T., Mašić, N. (2020). Body condition as an indicator of cow welfare. Acta Agriculturae Serbica, 25(50), 187-192.

Leopold, J.H., van Hooijdonk, R.T., Sterk, P.J., Abu-Hanna, A., Schultz, M.J., Bos, L.D. (2014). Glucose prediction by analysis of exhaled metabolites - a systematic review. BMC Anesthesiology, 14, 46. doi: 10.1186/1471-2253-1446. 
Loisel, J., Duret, S., Cornu'ejols, A., Cagnon, D., Tardet, M., Derens-Bertheau, E., Laguerre, O. (2021). Cold chain break detection and analysis: Can machine learning help? Trends in Food Science and Technology, 112, 391-399.

Manzano, M., Cecchini, F., Fontanot, M. et al. (2015). OLEDbased DNA biochip for Campylobacter spp. detection in poultry meat samples. Biosens Bioelectron, 66, 271-276.

Martins, S.A.M., Martins, V.C., Cardoso, F.A., Germano, J., Rodrigues, M., Duarte, C., Bexiga, R., Cardoso, S., Freitas, P.P. (2019). Biosensors for On-Farm Diagnosis of Mastitis. Frontiers in Bioengineering and Biotechnology, 7(186), 119.

Mason-D`Croz, D., Bogard, J.R., Herrero, M., Robinson, S., Sulser, T.B., Wiebe, K., Willenbockel, D., Godfray, H.C.J. (2020). Modelling the global economic consequences of a major African swine fever outbreak in China. Nature Food, 1, 221-228.

McAfee, A. J., McSorley, E. M., Cuskelly, G. J., Moss, B. W., Wallace, J. M., Bonham, M. P., et al. (2010). Red meat consumption: An overview of the risks and benefits. Meat Science, 84(1), 1-13.

Mohebi, E., Marquez, L. (2015). Intelligent packaging in meat industry: An overview of existing solutions. Journal of Food Science and Technology, 52(7), 3947-3964.

Montrose, A., Creedon, N., Sayers, R., Barry, S., O`Riordan, A. (2015). Novel single gold nanowire-based electrochemical immunosensor for rapid detection of bovine viral diarrhoea antibodies in serum. Journal of Biosensors and Bioelectronics, 6(3), 1-7.

MSU. (2018). Feeding the world in 2050 and beyond - Part 1: Productivity challenges. Michigan State University Extension. https://www.canr.msu.edu/news/feedingthe-world-in-2050-and-beyond-part-1 (accessed on September 22, 2021).

Nastasijević, I., Milanov, D., Velebit, B., Djordjević, V., Swift, C., Painset, A., Lakićević, B. (2017). Tracking of Listeria monocytogenes in meat establishment using Whole Genome Sequencing as a food safety management tool: A proof of concept. International Journal of Food Microbiology, 257, 157-164.

Nastasijević, I., Branković Lazić, I., Petrović, Z. (2019). Precision livestock farming in the context of meat safety assurance system. The $60^{\text {th }}$ International Meat Industry Conference MEATCON2019. IOP Conf. Series: Earth and Environmental Science, 333. doi:10.1088/17551315/333/1/012014.

Nastasijević, I., Proscia, F., Bošković, M., Glišić, M., Blagojević, B., Sorgentone, S., Kirbis, A., Ferri, M. (2020a). The European Union control strategy for Campylobacter spp. in the broiler meat chain. Journal of Food Safety, 40, 5. https://doi.org/10.1111/jfs.12819.

Nastasijevic, I., Veskovic, S., Milijasevic, M. (2020b). Meat Safety: risk based assurance systems and novel technologies. Meat Technology, 61(2), 97-119. https://doi.org/10.18485/meattech.2020.61.2.1.

Neethirajan, S., Tuteja, S.K., Huang, S-T., Kelton, D. (2017) Recent advancement in biosensors technology for animal and livestock health management. Biosensors and Bioelectronics, 98, 398-407.

Neethirajan, S., Ragavan, K.V., Weng, X. (2018). Agro-defense: Biosensors for food from healthy crops and animals, Trends in Food Science and Technology, 73, 25-44. https://doi.org/10.1016/j.tifs.2017.12.005.

Neethirajan, S. Kemp, B. (2021). Digital Livestock Farming. Sensing and Bio-Sensing Research, 32, 100408. https://doi.org/10.1016/j.sbsr.2021.100408.

Norton, T., Chen, C., Larsen, M.L.V., Berckmans, D. (2019). Precision livestock farming: building 'digital representations' to bring the animals closer to the farmer. Animal, 13(12), 3009-3017. https://doi.org/10.1017/S175173111900199X.

El Idrisi, A.H., Dhingra, M., Larfaoui, F., Johnson, A., Pinto, J., Sumption, K. (2021). Digital technologies and implications for Veterinary Services. Revue scientifique et technique (International Office of Epizootics), 40(2), 1-24.
OECD/FAO. (2016). Agricultural outlook 2016-2025. http://www.fao.org/3/a-B0100e.pdf (accessed on June $23,2020)$.

Raheem, D., Shishaev, M., Dikovitsky, V. (2019). Food System Digitalization as a Means to Promote Food and Nutrition Security in the Barents Region. Agriculture, 9(8), 168. https://doi.org/10.3390/agriculture9080168.

Shang, L., Heckelei, T., Gerullis, M.K., Borner, J., Rasch, S. (2021). Adoption and diffusion of digital farming technologies - integrating farm-level evidence and system interaction. Agricultural Systems, 190, 103074. https://doi.org/10.1016/j.agsy.2021.103074.

Sikorski, Z. (1990). Seafood: Resources, Nutritional, Composition, and Preservation. $1^{\text {st }}$ Edition, CRC Press. https://doi.org/10.1201/9781003068419.

ISBN 9781003068419

Sofos, J. (2008). Challenges to meat safety in the $21^{\text {st }}$ century. Meat Science, 78, 3-13.

Tarasov, A., Gray, D.W., Tsai, M.Y., Shields, N., Montrose, A., Creedon, N., Lovera, P., O'Riordan, A., Mooney, M.H., Vogel, E.M. (2016). A potentiometric biosensor for rapid on-site disease diagnostics. Biosens Bioelectron, 79, 669678.

Tullo, E., Finzi, A., Guarino, M. (2019). Review: Environmental impact of livestock farming and Precision Livestock Farming as a mitigation strategy. Science of the Total Environment, 650, 2751-2760.

Torky, M., Hassanein, A.E. (2020). Integrating blockchain and the internet of things in precision agriculture: Analysis, opportunities, and challenges. Computers and Electronics in Agriculture, 178, 105476. https://doi.org/10.1016/j.compag.2020.105476.

United Nations Department of Economic and Social Affairs (UNDESA) Population Division. (2017). World population prospects: the 2017 revision, key findings and advanced tables. Working paper No. ESA/P/WP/248. UNDESA, New York, United States of America. https://population.un.org/wpp/Publications/Files/WPP 2017_KeyFindings.pdf (accessed on September 22, 2021).

Vidic, J., Manzano, M., Chang, C.M., Jaffrezic-Renault, N. (2017). Advanced biosensors for detection of pathogens related to livestock and poultry. Veterinary Research, 48(11), 122.

Vongsawasdi, P., Noomhorm, A. (2015). Bioactive Compounds in Meat and their Functions. In: Noomhorm, A., Ahmad, I., Kumar, A. (Eds.). Functional Foods and Dietary Supplements: Processing Effects and Health Benefits. John Wiley \& Sons, Ltd, 113-138. https://doi.org/10.1002/9781118227800.ch5.

Wang, R., Wang, Y., Lassiter, K., Li, Y., Hargis, B., Tung, S., Berghman, L., Bottje, W. (2009). Interdigitated array microelectrode based impedance immunosensor for detection of avian influenza virus H5N1. Talanta, 79(2), 159-164.

WHO. (2020). Food safety. Key facts. http://www.who.int/news-room/factsheets/detail/food-safety (accessed on September 24, 2021).

Wu, W., Zhao, S., Mao, Y., Fang, Z., Lu, X., Zeng, L. (2015). A sensitive lateral flow biosensor for Escherichia coli 0157:H7 detection based on aptamer mediated strand displacement amplification. Analytica Chimica Acta, 25, 861, 62-68. doi: 10.1016/j.aca.2014.12.041.

Yamaguchi, M., Matsuda, Y., Sasaki, S., Sasaki, M., Kadoma, Y., Imai, Y., Niwa, D., Shetty, V. (2013). Immunosensor with fluid control mechanism for salivary cortisol analysis. Biosens Bioelectron, 41, 186-191.

Yang, M., Caterer, N.R., Xu, W., Goolia, M. (2015). Development of a multiplex lateral flow strip test for foot-and-mouth disease virus detection using monoclonal antibodies. Journal of Virological Methods, 221, 119-126.

Yoo, S.M., Lee, S.Y. (2016). Optical biosensors for the detection of pathogenic microorganisms. Trends in Biotechnology, $34,7-25$. 